\title{
Buses and Breaking Point: Freedom of Expression and the 'Brexit' Campaign
}

\author{
Andrew Reid ${ }^{1}$ \\ Published online: 29 May 2019 \\ (C) The Author(s) 2019
}

\begin{abstract}
In the aftermath of the 'Brexit' referendum two pieces of campaign material used by the successful Leave campaign proved controversial: a slogan on the side of a bus fallaciously implying that leaving the EU would necessarily free up $£ 350$ million a week for the NHS; and a poster stating that Britain was at "Breaking Point" - purportedly due to an influx of migrants - that was redolent of Nazi propaganda. This paper analyses and develops some criticisms that were levelled at the Leave campaigners who authorised these from the perspective of political liberalism. It concludes that those behind the Breaking Point poster could justifiably have been subject to non-criminal sanction by institutions such as the Electoral Commission, but that this is not the case for the NHS bus. The Breaking Point poster warrants sanction because it belongs to a category of hateful speech that propagates false and discriminatory beliefs about its targets. Where these are disseminated by those in authority or of high status, such as political campaigns, they can strengthen these beliefs amongst the rest of the population. This can lead to members of the targeted group being unable to deliberate effectively as they are not treated with adequate respect in political discussions, which in turn undermines the process of public justification. As a result, it undermines public justification in a way that false factual claims do not, eventhough in this case the NHS slogan appears to have had a greater effect on the referendum result.
\end{abstract}

Keywords Hate speech · Legitimacy · Public reason · Brexit · Propaganda

\section{Introduction}

This paper argues that when hateful speech is used in political campaigns, the parties or groups that use it might justifiably be subject to non-criminal sanctions such as the withdrawal of institutional support and recognition. To make this case, I draw a contrast between hateful material and campaign material that misleads voters, and argue that even where the latter

Andrew Reid

a.reid@bham.ac.uk

1 University of Birmingham, Birmingham, UK 
appears to have a greater effect on voting behaviour, it should not be subject to the same restrictions. I use two illustrative examples of controversial pieces of campaign material from the 2016 'Brexit' referendum. These were: the claim emblazoned on the side of the 'battle bus' used by Vote Leave, the official campaign organisation arguing in favour of Brexit, that "We

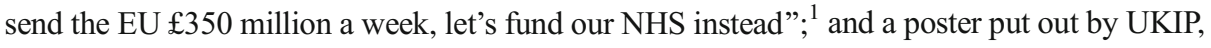
the major Eurosceptic party in Britain, depicting a line of refugees from the Middle East with the slogan "Breaking Point" displayed in red (hereafter I refer to the former as the NHS bus, and the latter as the Breaking Point poster).

My personal reaction to the former was one of indifference; I accept that politicians play fastand-loose with facts. On the other hand the Breaking Point poster appeared at best distasteful and at worst racist. In this paper, I suggest that regulation ought to reflect this intuition; that there is indeed something distinctly wrong about material like the Breaking Point poster that warrants regulation. This has not been the reaction of many 'Remainers'. ${ }^{2}$ Some have since questioned the legitimacy of the referendum result given the misinformation that pervaded the campaign. To those making this case, the NHS bus represents the apotheosis of a campaign divorced from facts.

There is certainly something to this position; if nothing else, the NHS bus seems to have contributed positively to the Leave vote, whilst the Breaking Point poster most likely did not. There is also a legitimate theoretical worry. The obfuscation of facts makes it more difficult for citizens to access the relevant information to assess and deliberate on policies and laws. Depending on the view of democracy you subscribe to this is undesirable at best, and may even harm the legitimacy of the procedure at worst. However, the duty not to use campaign material like this is not an enforceable one. The state ought not intervene to penalise those who produce campaign material with flagrant lies in it; instead, in a reasonably just, liberal society, it ought to be the job of citizens, political opponents and the media to scrutinise the claims made by political campaigns. The most the state can do is to ensure that the information and resources that citizens need to do this are readily available.

In contrast, the Breaking Point poster warrants non-criminal sanction applied by the Electoral Commission, or related bodies, and directed at the campaign groups and individuals behind it. The difference between this and the NHS bus is that it expresses hateful and discriminatory sentiments. Rather than making a claim that can be challenged, imagery like this cultivates an environment where some citizens cannot participate fully in politics, especially when it is deployed by actors with perceived authority. Admittedly, the claim that acts of speech can have this effect is difficult to provide evidence for, and the case for restriction is provisional and contingent on such evidence. It is therefore worth separating the two parts of my argument; the main hypothesis that speech that has this effect might be subject to non-criminal or 'soft' sanctions, which is conditional; and a secondary argument that there is sufficient evidence that speech acts like the Breaking Point poster have exclusionary effects to justify such sanctions in this case.

In the final section of the paper, I locate my position relative to existing debates around hate speech and democracy and respond to the worry that sanctions on political parties of the kind that I describe are anti-democratic. I argue that restricting material like the Breaking Point poster might actually enhance the democratic process by protecting people from being unfairly marginalised in deliberation. To make this argument, and throughout the paper, I draw upon

\footnotetext{
${ }^{1}$ I have inserted the comma into this quote - on the bus there is a line break between 'week' and 'let's'.

${ }^{2}$ I use the colloquial terms 'Remainers' and 'Leavers' to refer to campaigners on either side.
} 
the idea of effective political voice or the capacity to take part in the shaping of laws. I base this on an account of legitimacy achieved through public justification.

\section{Democracy and Effective Political Voice}

\subsection{The Importance of Political Voice}

In this paper I make some broad assumptions about the nature of democracy, and the role of freedom of expression in this. My underlying assumption is that democracy requires the co-authorship of laws amongst citizens, and that this requires that citizens have an equal political voice. By 'equal political voice', I do not mean that each citizen has the same influence on laws, but that they have the same effective capacity to participate in deliberation. The entitlement to an equivalent political voice is a relational one - it is the entitlement to be taken seriously by others in a mutually respectful environment. It is, to use Williams' terminology, a right that we must "secure", rather than something that can be possessed formally" (2005: 107). This requires some adherence to deliberative norms. For political voice to be effective for all, citizens must enter deliberation prepared to justify their opinions, and to listen to others and in some cases change their minds (Dryzek 2000: 15).

Citizens do not always enter deliberation in this spirit. What is more, I assume that the state cannot coerce citizens into doing so in an unobjectionable way. As such, fair political voice can only ever be secured in a provisional and contingent way through institutional arrangements. These extend beyond just the core political rights common to all democratic theories. In addition it requires things like adequate platforms for political groups, funding and support for political parties, appropriate provision and regulation of any state media outlets and civic education. All of this requires the regulation of these institutions and systems to be conducted in a way that the various parts work together.

\subsection{Political Voice and Public Justification}

The basis for this claim about political voice is a wider acceptance that the process of legitimising laws requires a process of public justification. I accept at the outset something like Rawls' constraint on legitimacy. This is that:

"our exercise of political power is fully proper only when it is exercised in accordance
with a constitution the essentials of which all citizens as free and equal may reasonably
be expected to endorse in the light of principles and ideals acceptable to their common
human reason. ... Only a political conception of justice that all citizens might be
reasonably expected to endorse can serve as the basis for public reason and
justification". (Rawls 2005: 137)

I use the term 'something like' because in this paper I address all accounts of legitimacy that retain two main tenets of Rawls' thought: that legitimate laws are based on reasons that are somehow acceptable to all, and that citizens must be prepared to justify their position publicly, in a way that others can observe, scrutinise and challenge. A more general public justification principle is that "[a] coercive action 
$\mathrm{C}$ is justified if and only if each and every member of the public $\mathrm{P}$ has (a) conclusive reason(s) R to endorse C" (Vallier 2011, 262). This encompasses both of the dominant theories of public reason at this point - the Rawlsian model and the alternative 'convergence' approach.

This standard is fairly broad and encompasses a variety of liberal views that argue laws ought to be justified through appeal to the reason of other citizens (Larmore 2015: 78-9). It is also a feature of most accounts of deliberative democracy: for example Gutmann and Thompson see a principle of reciprocity and an obligation to justify coercive laws to all other citizens as one of the underlying principles of their theory (2000: 167). ${ }^{3}$ There remains disagreement as to whether a fuller, deliberative system of democracy is required by public justification (see Gaus and Vallier 2009). For the purposes of this paper, I assume simply that some process by which laws are scrutinised in public is necessary for their legitimacy and for citizens to effectively participate in the co-authorship of laws.

\section{The NHS Bus Poster}

The now-infamous NHS bus was deployed by Vote Leave, the official campaign group for Brexit as designated by the Electoral Commission. It stated 'We send the EU £350 million a week, let's fund our NHS instead'. Some Leave campaigners have argued that they used the figure of 'the cost of an NHS hospital' in order to illustrate how expensive remaining in the EU was. Conversely, disgruntled Remainers have argued that by using the claim so prominently, it would have appeared to some voters that Brexit would necessarily free up $£ 350$ million to spend on the NHS. Leave campaigners have consistently backed away from this claim since the vote (Griffin 2016).

There have been some preliminary challenges to the use of the image. For example, the Advertising Standards Agency received 374 complaints. ${ }^{4}$ A pressure group emerged called Vote Leave Watch that was devoted to making the government come up with the money, seemingly in an effort to force as many Leavers as possible to admit that the bus was misleading. There have even been suggestions that the referendum ought to be repeated because of the dishonesty of the leave side, and the belief that "the leave side won because they... promised something that does not exist" (Rothstein 2016).

Though I am not convinced that the NHS bus is uniquely problematic amongst lies in political campaigns, it is worth unpacking this objection. Whilst it is true that calculating the cost of EU membership for the UK is complicated, the claim was inaccurate by any reasonable measure. I assume here that there was never going to be $£ 350$ million available to the NHS weekly as a direct result of the Brexit vote. Even if the UK exchequer were to have an extra $£ 350$ million per week in its coffers as a result of Brexit, there is no reason to assume any government would choose to spend all of this on the NHS. More importantly, whilst the UK 'sends' $£ 350$ million to the EU as a gross figure, it also receives a rebate, so the net figure is much less than this. There are other complicating factors as well - part of the UK's contribution to the EU goes on overseas development projects, the overall funding levels of which are an

\footnotetext{
${ }^{3}$ See also Bohman and Rehg, who identify this as the common feature of various accounts of deliberative democracy (1997: xiii).

${ }^{4}$ See Parker (2016) for a journalistic discussion of this.
} 
independent commitment of the British government. It did not factor in the potential cost of any subsequent trade deal with the EU, or of any potential lowering of government incomes as a result of any post-Brexit economic downturn; whilst claims about economic consequences were the result of modelling, and predictions, the NHS bus claim did not make any attempt to factor in variables of this kind. ${ }^{5}$

A naïve defence of the Leave campaign might be that because the figure is hard to reach, they went for the best possible figure for their cause. A cynic would see it as a lie designed to convince voters of a simple untruth. Both of these interpretations of events seem inadequate, especially given that the statements of key Leavers and commentators on the campaign suggest more subtle and nuanced motivations. Dominic Cummings, the political operative who acted as the campaign chief for Vote Leave notes in a personal blog that:
"Pundits and MPs kept saying 'why isn't Leave arguing about the economy and living standards'. They did not realise that for millions of people, $£ 350 \mathrm{~m} / \mathrm{NHS}$ was about the economy and living standards... It was clearly the most effective argument... with almost every demographic. Even with UKIP voters it was level-pegging with immigra- tion. Would we have won without immigration? No. Would we have won without $£ 350 \mathrm{~m} / \mathrm{NHS}$ ? All our research and the close result strongly suggests No. Would we have won by spending our time talking about trade and the Single Market? No Way." (Cummings 2017)

This is not to say that he believes that people believed the figure, so to speak. Instead, he refers at various points in the blog to the idea of telling "compelling stories", and connecting the EU to a general dissatisfaction with the economic state of the country (Ibid.). The idea behind the poster seems to have been to make the debate about the costs rather than the benefits of EU membership. As Shipman puts it in his account of the campaign, "[e]very time there was a row about the size of the cost to taxpayers of EU membership, it simply reinforced in voters' minds that there was a high cost" (2017: 259). The idea here was that as soon as any Remainer responded to the NHS bus with a response of the kind: 'actually, EU membership costs $£$ X million instead', they were already on the back foot because they were talking about costs not benefits. It also enabled Vote Leave to place their logo next to the NHS logo, an institution that the public values highly. None of these purported objectives depended upon people being convinced of the specifics of the claim. Despite this, speech acts of this kind can still have damaging effects on democratic discourse by 'muddying the waters' in factual deliberations.

The NHS bus can therefore be thought of as an example of what Stanley calls "undermining propaganda". These are speech acts that involve "erecting difficult epistemic obstacles to recognising tendencies of goals to misalign with certain ideals" (2015: 57). He applies this idea fairly broadly and refers to the deeper ideological or moral commitments that underpin society, whilst in this case I apply it to factual deliberations. The key phrase in Stanley's definition is "epistemic obstacle". The NHS bus introduced such obstacles because it made it harder for a member of the public to establish what the costs and benefits of Brexit are. It did this by wrongly problematising the epistemic authority of some bodies and figures, and in doing so eroding the set of common factual reference points in the debate.

This is a problem for a democratic process that depends on mutual justification and citizens having a political voice, as this depends on areas of agreement. This agreement must exist at the level of democratic norms, but also upon a set of epistemic standards. In Rawlsian theories of public

\footnotetext{
${ }^{5}$ For a full breakdown of the problems with the claim see Reuben (2016)
} 
reason these include a set of common facts that can be used as reference points in deliberation. Rawls argues that we have an obligation to draw upon commonly agreed upon facts, specifically "accepted general beliefs and forms of reasoning found in common sense, and the methods and conclusions of science where they are not controversial" (2005: 224). The other dominant school of thought in public reason theorising, the 'convergence' view does not make this specific demand, but does stipulate that citizens should avoid "gross epistemic error" (Vallier 2014: 106).

There is a question of how accessible specialist knowledge, such as that necessary to understand the minutiae of economic policy, is to the general public (Herzog 2012: 273). In practice there is a trade-off between widening participation in deliberation and the set of commonly agreed upon facts that can be drawn upon (Cohen and Fung 2004: 27). This is because if we accept that citizens have divergent cognitive abilities and standards of reasoning, we ought not draw up a set of facts that we treat as commonsense, but that actually are beyond the reasoning capacities of the majority of citizens. ${ }^{6}$ The problem with undermining propaganda is that it is not an attempt to mediate this trade-off - by challenging the claims of experts that are not accessible to lay-people, say - but rather that it eliminates common reference points in political discourse by obscuring complicated issues. In doing so it undermines deliberation according to the standards of public justification that I have set out. It does this by reducing the pool of shared knowledge (if we accept a Rawlsian view) or increasing the chance of serious error (if we take the convergence view).

The troublesome function of the NHS bus, then, is to neutralise the discussion of the economic impact of Brexit by increasing scepticism of all factual claims, and presenting all predictions as equally bad. It nullifies the issue by reducing the set of commonly accepted, relevant facts and therefore making it harder to come to judgments about the effects of different policy options.

\subsection{Should Material like this be Regulated}

The central problem here is that there is a strong incentive to argue against commonly held beliefs because the mere act of doing so will lead to some people doubting the fact, meaning that the belief is no longer commonly held. The set of facts upon which there is a consensus can therefore be eroded intentionally by enterprising, but insincere, dissenters. To avoid this situation requires the imposition of at least some kind of external epistemic standard by which these facts might be judged. In practice there are a number of risks to the state imposing such a standard itself, at least by silencing those who do not accept or acknowledge it. As I noted at the start, the state cannot coercively enforce a deliberative spirit. I also assume that enough political actors violate epistemic norms enough of the time that actually trying to prevent the dissemination of misleading information risks overreach and cuts against a liberal belief that the state should interfere as little as possible in political debates. Interference is problematic because if the state limits the terms of political debate, it might prevent people from raising alternatives or objections to laws such that the laws produced cannot be described as publicly justified. ${ }^{7}$

Such coercion might still be warranted in cases like the NHS bus that have a significant distortionary effect on deliberation if there were no alternative. However, fact-checking

\footnotetext{
${ }^{6}$ My understanding of these divergent abilities and standards falls roughly in line with that described by Gaus See Gaus (2011: 254-7) for his argument that the standards of reasoning required ought not be to burdensome, and (276-9) for his account of plural standards of moral reasoning.

${ }^{7}$ See final section for a brief summary of this position.
} 
remains a job that citizens can perform. The NHS bus might have made it slightly harder by causing wrongful doubt in epistemic authorities, but it did not make it impossible. In liberal democracies citizens have the capacity to check the veracity of claims; to challenge those that make them; and to seek to persuade others of their view. Whilst I argue in the next section that some speech acts can undermine participation in this process, and therefore warrant regulation, I do not believe this is the case for factually misleading claims.

To illustrate this, consider Scanlon's argument that certain kinds of subliminal advertising ought to be subject to regulation because of the way that it undermines the autonomy of those influenced by it (2003: 90-2). Could the NHS bus poster not be said to do the same, in terms of political autonomy, by influencing people in ways they could not perceive?

I do not think so. Whilst I do not offer a judgment on Scanlon's overall argument here, I do not believe that the NHS bus meets his criteria for problematic (and therefore justly subject to regulation) subliminal advertising. Scanlon argues that many acts of expression have subliminal, which is to say unperceived, effects on the listener. What sets apart the subset of subliminal advertising that ought to be regulated is that it convinces people that they have "good reason" to do something when they do not (91). I do not believe this is the case with the NHS bus. Whilst we might plausibly argue that the NHS bus was meant to influence people to vote for Brexit, it is harder to prove that the intent was to fool them into doing so when they had good reason not to. It is hard to make this case stick for two reasons. First, it requires claims about what people's true interests are in these cases, and what might count as a good reason. These kinds of claim are difficult for liberals who acknowledge pluralism of reasons and interests to sustain. It appears objectionable from a liberal perspective to say that voters who support policies that appear contrary to their economic interests do so for 'bad' reason, given the myriad other reasons they might have. Second, the NHS bus was sufficiently debated that it cannot be considered truly subliminal. It is likely that, despite the negative effects of the poster, citizens spent more time critically reflecting on it than they do most adverts.

The role for the state in this situation is to ensure that citizens have the time and information to take on this role in deliberation, and to inculcate relevant reasoning skills and attitudes in education. It can also help the process of scrutinising claims along by using 'positive speech'. In this case, whilst the NHS bus ought not have seen Vote Leave lose their accreditation as the 'official' campaign, official bodies might have intervened to make the relevant information available to the public, possibly through 'positive' speech acts (see, for example, Brettschneider (2012)). ${ }^{8}$ This would help people who are limited in the time and effort they have to spend looking through treasury reports trying to establish the true cost of Britain's membership of the EU, and the likely economic impact of leaving. State bodies ought to release factual information in these cases, and state broadcasters have a duty to present the relevant information in an accessible way.

\section{The Breaking Point Poster}

I argued in the previous section that there are some things that, in a democracy, ought to be left to citizens, and that ultimately being able to scrutinise the factual claims of political campaigns

\footnotetext{
${ }^{8}$ It has been suggested to me that institutions like the Office of National Statistics might play a prominent role in this effort.
} 
is one of them. In this section I argue that political campaign material that engages in hateful speech might be restricted, and that the Breaking Point poster is an example of this.

At this point it is worth clarifying my argument that the Breaking Point Poster counts as "hate speech". I believe that it does count as hate speech, and that it should be subject to regulation. However, I define both hate speech and regulation broadly. I use the term 'hate speech' as Brown does to describe a set of acts of expression that share a family resemblance, specifically the targeting of protected or non-dominant groups within a society on grounds of characteristics like race or gender, and the use of vituperative language or imagery (2017a). To this I would add that hateful speech conveys a significant lack of respect towards its target by drawing upon, or fostering, harmful and untrue discourses about groups within society.

The Breaking Point Poster fits this definition. It presents non-white migrants as a hostile or invading force and an imminent threat to British resources. The most plausible interpretation of this imagery is that it was an attempt to stir racial animus amongst a subset of Leave voters. The poster has been likened to an image used by Nazis. Even if we do not accept this, it is hard to interpret it as not singling out recent arrivals in the country specifically and, given the fascistic undertones, non-whites, for differential treatment.

Brown does not believe all speech acts of this kind should be criminalised, or subject to one single response, arguing that:

"[T]he ordinary concept hate speech denotes a heterogeneous collection of phenomena held together by family resemblances rather than a single essential feature, then there is no earthly reason for that society not to start to look for a plurality of ways of responding to hate speech, and to embrace the idea that the criminal law is not the only way of combating hate speech" (2017a: 610).

In this spirit, whilst the Breaking Point poster lies at the margins of hateful speech, it should not be subject to criminal sanction. However, it does transgress the norms expected of political campaigns because of its potential effect on political voice, so should be subject to limited sanctions within this sphere. Such hate speech can, when practiced by political elites, have harmful effects on the democratic forum, and as such might be subject to measures that amount to partial censorship when practised by political parties or recognised campaign groups.

The effects that I am concerned with are not the effect of speech acts on the result of the specific campaign, but on the democratic process as a whole. In this case, the conventional wisdom is that, whilst the NHS bus was important in a narrow victory, the Breaking Point poster had little impact, and if it did it is likely to have harmed the Leave vote. It was released on the day that Jo Cox, a Member of Parliament, was murdered, and most prominent Leavers disowned it. Some even set about trying to prevent Farage from using similar imagery in the final week of the campaign, believing that it would hurt their cause (Shipman 2017: 291). Whilst it is a matter of considerable speculation as to whether the Leave side would have won had they not used the claim about the NHS so prominently, there is no serious thought that in a counter-factual universe where the Breaking Point poster was not released Remain would have carried the day.

Speech acts like the Breaking Point poster warrant sanction because they make it harder for some people to utilise their democratic voice in general, rather than because of its effect on a particular vote. The targets are not immediately harmed by such discourses, but if they gain traction political debate is framed in such a way that they are treated as outsiders to the democratic process. Indeed, recent migrants - the primary though not exclusive target of the poster - would have been unable to vote in the referendum. Nonetheless, it remains the case that they ought still be able to contribute to deliberation on an issue that affects them, as I 
believe the Brexit vote does, and to participate in future debates where they are more direct stakeholders. ${ }^{9}$ Persistent use of imagery like the Breaking Point poster by those in positions of relative authority can cause a shift in public perceptions that leads to some groups not being taken seriously in political deliberation. This amounts to a de facto exclusion from the process of deliberating over laws due to the loss of an effective political voice.

Something like this effect has been discussed in other work on hate speech, for example when Waldron discusses "group defamation" or "group libel" (2012: 39-40). This is the spreading of mistruths about groups within society that causes them to be treated unfairly or unjustly. He also emphasises the loss of dignity that occurs when we are frequently part of a "disfiguring social environment" where such ideas persist (117). The "disfiguring social environment" I am concerned with is one that contributes to a situation where some are treated as inferiors in political deliberation. This undermines effective political voice, because it causes others to treat them differently.

The loss of esteem in the eyes of other citizens can lead to members of groups targeted by hate speech suffering an epistemic injustice (Fricker 2007). One manifestation of epistemic injustice is "testimonial injustice", the injustice of being doubted as a knower, or of having the integrity of one's knowledge challenged (1-2). Group libel can generate this kind of an injustice because it propagates negative stereotypes of a kind that can become latent assumptions in public discourse. Minority groups can therefore be forced to deliberate as if such stereotypes are true in order to facilitate a productive dialogue; Stanley uses the example of African Americans who end up participating in debates where racist stereotypes that they are lazy or violent persist (2015: 163). This analysis can be applied the Breaking Point poster. It depicts non-white citizens and recent migrants as a hostile force, and a drain on resources. Deliberating when these traits are assumed at the outset means accepting disrespectful falsehoods, and a concurrent loss of perceived credibility. It is to deliberate at a disadvantage, as it requires the internalisation of a norm that the speaker is less trustworthy or able.

The status of the speaker matters in these cases because it determines the extent to which what they say impacts on the informal norms that underpin deliberation. The idea that a group is inferior is far more likely to become normalised over time if it is a trope that is drawn upon frequently by those in authority, in part because of the "licensing" effect this can have (Maitra 2012: 111-6). Where actors who have a certain status within the political system use overtly racist material, like the Breaking Point poster, it can, over time, affect the perception of its targets amongst other citizens and erode the stigma attached to such views. The fact that it is politicians, or those involved in recognised political campaigns, matters here. When they violate a norm of equal respect they violate a requirement to treat people as equal, and they do so from a position of relatively high status. It is the combination of the relative status of UKIP and the duties they have as a political party that means their acts are worthy of soft censorship, whilst normal citizens who presented similar imagery in other contexts would not be. So, for example, an artist might use similar imagery in a provocative piece and not warrant a similar sanction, in part because they do not receive some of the benefits that politicians and campaigners do, so these cannot be withdrawn. ${ }^{10}$

\footnotetext{
${ }^{9}$ Though I cannot defend it here, my belief is that the normative justificatory constituency, i.e. those entitled to a say, extends beyond British citizens in this case. One reviewer noted that if this is the case, non-citizens who ought to be able to vote but cannot, and are further disadvantaged in deliberation, face a compound injustice.

${ }^{10}$ I focus on officially designated groups because they are highly influential, and because of the formal benefits they receive from state bodies. I do not deny that other groups that exert significant influence might have other soft sanctions applied.
} 
The NHS bus was endorsed by politicians with a higher profile than Nigel Farage, so there was the potential for a more profound 'licensing effect'. What matters, though, is what is being licensed. With the NHS bus, any licensing effect would have served to inculcate a wrongful mistrust of experts, or disregard an epistemic duty. In the case of the Breaking Point poster it is a license to disregard other citizens.

Both of these effects can be understood as forms of epistemic injustice, and that framework explains why the injustice suffered by targets of racist speech is more severe. In the case of the NHS bus, some individuals suffer an epistemic injustice because others make incorrect judgments about their reasoning capacities on a systematic basis and wrongfully disregarding their testimonies - in this case causing people to wrongly underestimate some 'experts' and politicians whilst having too much faith in others. This kind of epistemic injustice is very widespread, as we often make quick judgments about the epistemic credentials of others with limited evidence, and get this wrong (Origgi 2012). Similarly racist speech can cause other actors in a deliberation to wrongfully mistrust the testimony of the targets.

Why is this effect more severe in the latter case? Or, to put it differently, why are the epistemic injustices that people suffer as a result of being the targets of persistent racist speech worse from a democratic perspective? The answer lies in the connection between equal respect and the conception of effective political voice that I have drawn. Experts who are wrongly maligned, and putative authorities that are disregarded because of factually misleading claims that 'muddy the waters' retain a level of esteem such that we can reasonably expect that they will maintain a level of influence in deliberation. The epistemic injustices that accrue with the internalisation of racist norms are more severe. Crucially, given the account of political voice I have described, the kind of epistemic mistrust suffered by the targets of racist material is equivalent to a disrespect for the basic capacities of these individuals as reasoners; I am not convinced this is the case for those who suffer an epistemic injustice as a result of the NHS bus.

My argument is admittedly hard to provide evidence for, as it is difficult to show how attitudes to a particular group change over time, and the effects of this on deliberation. Not only that, but the effect of hateful speech on background norms is gradual and cumulative individual instances of hateful speech will only have a marginal effect. It also rests on the assumption that the structural disadvantages that the typical targets of racial hate speech like the Breaking Point poster face in political deliberation are more severe than those suffered by 'experts' in the last few years.

The combination of these structural disadvantages and the evidence we have of the effects of racist speech on deliberation is sufficient to underpin a provisional case for restriction. A wide ranging study of the effects of hate speech in Australia notes that a repeated theme raised by the targets of hate speech in interviews was that one of the harms they encountered as targets was "persuading others to believe negative stereotypes, conditioning the environment such that racism is normalized and causing hearers to imitate the behaviour of hate speakers" (Gelber and McNamara 2016: 336). Furthermore the study found that the effect of hate speech tended to be systemic; the silencing of political voice is something that occurs over time as a result of a combination of speech acts that undermine citizens' ability to "participate fully in society" rather than inhibiting their ability to shape a certain law (337). Whilst it is hard to show the silencing effect of the Breaking Point poster on specific individuals, it belongs to a kind of speech that inculcates this effect. ${ }^{11}$

${ }^{11}$ Burnett (2017: 87) offers a breakdown of the rise in racist incidents and hate-crimes after the referendum, which can be seen as further evidence for a shift in public attitudes. 
This kind of evidence has been cited as evidence that we should apply a "precautionary principle" to the censorship of hate speech, which states that there is a strong enough prima facie case that hate speech has harmful effects that make it worthy of restriction, so the burden of proof should be placed on those who believe it does not (Brown 2017b: 613-5). Whilst I have reservations about the application of such a principle when invoked to defend criminal sanctions, I believe that given the role of politicians, and their capacity to shape norms, that it should be applied to campaign regulation.

'Softer' sanctions that could be applied include limits to the activity, recognition of and institutional support for political parties and campaign groups. In the most extreme cases parties might be banned. This is still a severe punishment given that parties are the main vehicles many citizens have for advancing their interests in politics (Kirshner 2014: 72 ), and is disproportionate in this case. When evaluating measures that might limit the voice of political groups we must be mindful not only of their increased responsibilities, but also the countervailing argument that because politicians and parties are integral to articulating others' interests, there are independent reasons to protect their speech in some contexts that must be weighed against any restrictions (Sottiaux and Rummens 2012: 125).

There are, however, other 'softer' steps that might be taken. The UKIP-affiliated Leave.EU was passed over as the 'designated' leave campaign, and the Breaking Point poster ought to harm the chances of any of the key figures being part of a group that gains a similar designation in future. However, UKIP and Leave.EU were "permitted participants" in the referendum campaign, registered through the Electoral Commission. Concrete benefits of this status include being able to legally spend over $£ 10,000$ on the campaign and having access to the electoral register, whilst surveyed campaigns also note that they sought designation because of increased publicity and perceived legitimacy (Fisher and Rottweiler 2016: 7); all of these could be withdrawn. UKIP is also entitled to similar support and recognition as a political party and has, in the past, been entitled to a small amount of state funding through 'short money'. 12

Members of UKIP continue to feature prominently in the media, and a case can be made that the $\mathrm{BBC}$, a state broadcaster, might 'no-platform' them in future, or refuse to run party political broadcasts. There might even be a case for treating such speech acts as a sign of an individual politician like Farage being held in contempt of their office, though there is less precedent for this. There are, then, non-criminal sanctions of consequence that can be used against political parties in the UK system, and the goal of this article has been to show that these would be appropriate in this case.

The intent of the sanctions is to prevent distortionary effects on the process of deliberation. This means that we ought to consider sanctions only when the effect is particularly strong, rather than the intent being particularly bad, and that we should only do so when sanctions are effective (Kirshner 2014: 80-81). I believe the potential effect, given the status UKIP achieved, to be sufficient to warrant consideration of such sanctions for the reasons I set out above.

I am less sure about whether such sanctions would be effective in terms of actually producing the desired effect of diminishing UKIP's influence. UKIP are, after all, a populist party of sorts, and they might have gained traction by being able to point to an establishment

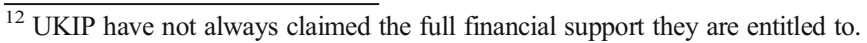


cover up. ${ }^{13}$ I argue here only that sanctions may, in principle, be justified, and that effectiveness is an empirical question that needs to be considered subsequent to this. ${ }^{14}$

\section{Responding to Existing Theories of Freedom of Expression}

I have argued that sanctions meant to restrict hateful expression by political parties or campaigns can enhance the democratic process by protecting the political voice of some citizens. This a narrow application of Brown's 'Nuanced Principle of Democracy', whereby restriction on some speech might be limited in order to ensure all citizens might participate politically as they are entitled to (2015: 195). It is a narrow application in two senses: first it depends on a particular view of what constitutes an equal political voice, and second because I focus on the regulation through non-criminal means of political parties. Whatever the overall merits of Brown's arguments, I suggest that something like the nuanced principle ought to apply in this arena, because of its importance to the democratic process.

This runs against a strong current in the literature that any restrictions on (even hateful) speech acts are necessarily anti-democratic. Post, for example, argues that the purpose of a right to freedom of expression is to ensure that all can participate in the coauthorship of the laws they are subject to (Post 2011: 482), whilst Dworkin sees freedom of expression as constitutive of a broader right "to contribute to the moral environment" (2009: viii). Heinze argues that freedom of expression is constitutive of democratic decision-making (2016: 14-18), and sees the absence of viewpoint-selective restrictions as essential to this legitimising function (22). Such arguments are important given that most accounts of public justification in the tradition I am operating in treats an expansive right to freedom of expression as necessary to the process of legitimising laws for similar reasons (Rawls 2005: 354). ${ }^{15}$

It is beyond the scope of this paper to fully discuss or rebut these. However, there are two reasons that I do not see these arguments as undermining my case for non-criminal sanctions in the Breaking Point poster example.

First, I have emphasised the importance of status in deliberation. The view I have of deliberation depends upon certain respectful relationships that hate speech appears to discourage. ${ }^{16}$ By drawing on the ideas of epistemic injustice and the thought that citizens ought to treat each other respectfully if deliberation is to work such that laws might be legitimate, I have shown that merely guaranteeing certain 'negative rights' is insufficient to ensure adequate status and voice in deliberation. When the state interferes in other citizens' speech acts in order to limit hate speech it might therefore be protecting this status in a substantial way. At this point the interlocutors listed above may point out that state limits on speech and expression

\footnotetext{
${ }^{13}$ There is a view that sanctions of the kind I describe are counter-productive. For example, Heinze argues that restrictions on hate speech lead to it being concealed using coded speech (2013: 596). In the political science literature, there is a general understanding that populist parties, which I consider UKIP to be, benefit from their outsider status and acts of censure might burnish this (see Taggart and Kaltwasser 2016: 217).

${ }^{14}$ For a view that frames the containment of the far-right in similar terms whilst grappling with this empirical question, see Rummens and Abts (2010).

${ }^{15}$ Some have argued that Rawls is incorrect to assume that such a wide-ranging right to freedom of expression is required by his own account of political legitimacy. See, for example, Bonotti (2015).

16 Jarymowicz (2014) criticises Post for his failure to take into account the "relational" aspects of democratic citizenship.
} 
remain inimical to democracy, even if this holds true. I do not completely disagree. However, the sanctions that I have suggested in this article do not amount to complete exclusion from the public sphere. The harms of this kind of regulation are therefore limited, and do not diminish or outweigh the argument in the previous section that regulating hate speech can help protect effective political voice.

The second difference is in how I see the network of institutions that fosters, supports and enables political parties to act as vehicles for citizens' interests, and thus enable citizens' political voice. In my view, we should treat the question of how to structure political institutions around how best to realise an ideal of equal political voice for all. In this discussion I treated freedom of expression as a right amongst many others that contributes towards this, and as a right that should be regulated differently in different contexts. When we think about the way political parties and campaigns are regulated we should not treat this as a 'neutral' environment, but rather a complex competitive system where the state uses various measures to foster, support and amplify the concerns of different parties. The state and other institutions offer a platform for campaigns, and this being withdrawn is not normatively equivalent to legal censorship.

A broader point is that democratic defences of free speech at any level, including as a constitutional right, depend on the understanding of democracy invoked. My case in this paper has depended on a particular account of democracy, and what a functioning democratic process looks like. The defences of unrestricted freedom of expression that I cite also depend on a detailed view of what democratic citizenship entails. ${ }^{17}$ I would suggest that differences of opinion on hate speech regulation in the context of democratic citizenship are often disagreements about the latter.

\section{Conclusion}

This article has argued that if a political party or campaign group engages in racist hate speech it might legitimately be subject to non-criminal sanctions that involve the withdrawal of institutional recognition and support. This is because the function of a political party is to operate within a system that enables citizens to participate in the coauthorship of laws, and hate speech delivered from a position of authority might serve to normalise or inculcate behaviour that undermines this. Efforts to distort the factual terms of political deliberation also have a harmful effect on the process of legitimising laws. However there are no grounds to restrict speech like this, because it does not undermine political voice in the same way. Applied to the two examples, the Breaking Point poster could plausibly have led to some citizens being less able to participate effectively in politics, whilst the NHS bus did not have the same effect on those who disputed the claim. I ended by suggesting some ways in which this discussion might respond to objections that arise from the literature connecting a wide-ranging right to freedom of expression with democratic legitimacy. I argued that where such theories depend on a 'thick' conception of political voice, non-criminal sanctions that curb hate speech might be permissible and consistent with a defence of freedom of expression on democratic grounds.

${ }^{17}$ Baker (2011) makes this point in his critique of Post. 
Acknowledgements This paper was originally presented at a workshop at Cardiff University in December 2016. Thank you to Matteo Bonotti, who organised the workshop and to all the participants for their constructive feedback. Thank you also to: Matteo (again) and Paul Billingham who have edited this Special Issue for their advice and feedback throughout the process of refining the paper; Laura Brace, Rob Jubb and Steve Cooke, who were my $\mathrm{PhD}$ supervisors when I did much of the early work on the paper; and various members of the Political Theory research group at the University of Birmingham, who offered helpful advice in the later stages of writing and revising the paper.

Open Access This article is distributed under the terms of the Creative Commons Attribution 4.0 International License (http://creativecommons.org/licenses/by/4.0/), which permits unrestricted use, distribution, and reproduction in any medium, provided you give appropriate credit to the original author(s) and the source, provide a link to the Creative Commons license, and indicate if changes were made.

\section{References}

Baker CE (2011) Is democracy a sound basis for a free speech principle? Va Law Rev 97(3):515-529

Bohman J, Rehg W (1997) Introduction to Deliberative Democracy: Essays on Public Reason. The MIT Press, London

Bonotti M (2015) Political liberalism, free speech and public reason. Eur J Polit Theo 14(2):180-208

Brettschneider C (2012) When the state speaks, what should it say? How democracies can protect expression and promote equality. Princeton University Press, Princeton

Brown A (2015) Hate speech law: a philosophical examination. Routledge, London

Brown A (2017a) What is hate speech part 2: family resemblances. Law \& Phil 36(5):561-613

Brown A (2017b) Hate speech Laws, legitimacy, and precaution: a reply to James Weinstein. Const Comment 32:599-617

Burnett J (2017) Racial violence and the Brexit state. Race \& Class 58(4):85-97

Cohen J, Fung A (2004) Radical Democracy. Swiss J Pol Sci 10(4):23-34

Cummings D (2017) 'On the Referendum \#221...' Blog available at: https://dominiccummings.com/2017/01/09 /on-the-referendum-21-branching-histories-of-the-2016-referendum-and-the-frogs-before-the-storm-2/ Accessed 9 December 2017

Dryzek JS (2000) Deliberative democracy and beyond: liberals, critics and contestations. Oxford University Press, Oxford

Dworkin R (2009) Foreword. In Hare I, Weinstein J (eds) Extreme Speech and Democracy. Oxford, Oxford University Press, v-ix

Fisher J, Rottweiler B (2016) Research among permitted participants at the EU referendum. Online document produced for the Electoral Commission https://www.electoralcommission.org.uk/_ data/assets/pdf_file/0003 /214806/Research-among-permitted-participants-at-the-EU-referendum-Final-Report-FINAL-web.pdf. Accessed 17 June 2018

Fricker M (2007) Epistemic injustice: power \& the ethics of knowing. Oxford University Press, Oxford

Gaus GF (2011) The order of public reason: a theory of freedom and morality in a diverse and bounded world. Cambridge University Press, Cambridge

Gaus GF, Vallier K (2009) The role of religious conviction in a publicly justified polity: the implications of convergence, asymmetry and political institutions. Philos Soc Crit 35(1-2):51-76

Gelber K, McNamara L (2016) Evidencing the harms of hate speech. Soc Identities 22(3):321-341

Griffin A (2016) Brexit: vote leave wipes NHS $£ 350$ claim... the independent. Available at: http://www. independent.co.uk/news/uk/home-news/brexit-vote-leave-wipes-nhs-350m-claim-and-rest-of-its-websiteafter-eu-referendum-a7105546.html. Accessed 28 November 2017

Gutmann A, Thompson D (2000) Why deliberative democracy is different. Soc Philos Policy 17(1):161-180

Heinze E (2013) Review essay: hate speech and the normative foundations of regulation. Int J Law Context 9(4): $590-617$

Heinze E (2016) Hate speech and democratic citizenship. Oxford University Press, Oxford

Herzog L (2012) Ideal and non-ideal theory and the problem of knowledge. J Appl Philos 29(4):271-278

Jarymowicz T (2014) Robert Post's theory of freedom of speech: a critique of the reductive conception of political liberty. Philos Soc Crit 40(1):107-123

Kirshner AS (2014) A theory of militant democracy: the ethics of combatting political extremism. Yale University Press, London 
Larmore C (2015) Political liberalism: its motivations and goals. In: Sobel D, Vallentyne P, Wall S (eds) Oxford studies in political philosophy: volume 1. Oxford University Press, Oxford, pp 63-88

Maitra I (2012) Subordinating speech. In: Maitra I, McGowan MK (eds) Speech and harm: controversies over free speech. Oxford University Press, Oxford, pp 94-118

Origgi G (2012) Epistemic injustice and epistemic trust. Soc Epistemol 26(2):221-235

Parker G (2016) The ASA can't regulate political advertisements. Here's why. The Guardian. Available at: https://www.theguardian.com/commentisfree/2016/jul/06/advertising-standards-authority-politicaladvertisements. Accessed 3 December 2017

Post R (2011) Participatory democracy and free speech. Va Law Rev 97(3):477-489

Rawls J (2005) Political liberalism (expanded edition). New York, Colombia University Press

Reuben A (2016) Reality check: would Brexit mean extra £350m a week for NHS?. BBC. Available at: https://www.bbc.co.uk/news/uk-politics-eu-referendum-36040060. Accessed 29 July 2018

Rothstein B (2016) It's perfectly sensible to want a second referendum. Here's why. New Statesman. Available at: https://www.newstatesman.com/politics/staggers/2016/09/its-perfectly-sensible-want-second-eureferendum-heres-why. Accessed 3 October 2016

Rummens S, Abts K (2010) Defending democracy: the concentric containment of political extremism. Political Stud 58:649-665

Scanlon TM (2003) Freedom of expression and categories of expression. Reprinted in: the difficulty of tolerance. Oxford University Press, Oxford, pp 84-112

Shipman T (2017) All out war: the full story of Brexit (revised edition). William Collins, London

Sottiaux S, Rummens S (2012) Concentric democracy: resolving the incoherence in the European court of human rights' case law on freedom of expression and freedom of association. I•CON 10(1):106-126

Stanley J (2015) How propaganda works. Princeton University Press, Princeton

Taggart P, Kaltwasser CR (2016) Dealing with populists in government: some comparative conclusions. Democratization 23(2):210-220

Vallier K (2011) Convergence and consensus in public reason. Public Aff Q 25(4):257-260

Vallier K (2014) Liberal politics and public faith: beyond separation. Routledge, New York

Waldron J (2012) The harm in hate speech. Harvard University Press, London

Williams B (2005) The idea of equality. Reprinted in: In the Beginning Was the Deed: Realism and Moralism in Political Argument. Princeton University, Oxford, pp 97-114

Publisher's Note Springer Nature remains neutral with regard to jurisdictional claims in published maps and institutional affiliations. 